\title{
MEDIA PREFERENCE ON NOTE-TAKING UPON STUDENTS' COGNITIVE PROCESS
}

\author{
by: \\ Luh Eka Susanti \\ Email : ekasusanti@stpbi.ac.id
}

\begin{abstract}
Note-taking acts as a tool to provide students for identifying and understanding the most important aspects of what they are learning (Borr et al., 2012). People who take notes typically retain more information which has a positive effect on learning (Titsworth in Borr et al., 2012). This study aims to investigate the preference and strategies used by the students when taking note. The medium they use indicates numbers of words generated in taking the note. There were three medium being utilized; longhand (traditional using pen and paper), laptop and mobile phone note. This study was conducted with 27 hospitality students who were learning Business English for Hotel and Tourism. Pre-test, post-test, interview, and questionnaire as well were couples of instruments used to obtain the data. The media preference they used indicates the numbers of word generated, abbreviations and symbols, looks, accurateness with the lecture time to process the note, format of notetaking, and the result of the test.
\end{abstract}

Keywords : note-taking, media preference, cognitive

\section{INTRODUCTION}

Different learners may have different ways to learn; some of them are likely enjoy the situation in silent way, or with music (it can be the classic one or even any types of music). In another hand, they will be more focus and fully understand with the help of the aids or even only by listening to the tone and analyze the teachers' lipsinc. Every student has their best way to learn. Some of them are visual learners, auditory learners, and the rest are kinesthetic learners. The aforementioned types of learning usually known as VAK learning styles (Visual, Auditory, and Kinesthetic/Tactile). It is based on modalities - channels by which human expression can take place and is composed of a combination of perception and memory.

Auditory learners may move their lips and read out loud. They may have difficulty with reading and writing tasks. They often do better talking to a colleague or a tape recorder and hearing what was said. They learn best through verbal lessons, discussions, talking things through and listening to what others have. Auditory learners interpret the underlying meanings of speech through listening voice, pitch, and speed. These learners often get benefit from reading text learn through listening to the tone.

Visual learners have two subchannels linguistic and spatial. Learners who are visual-linguistic like to learn through written language, 
such as reading and writing tasks. They remember what has been written down, even if they do not read it more than once. They like to write down directions and pay better attention to lectures if they watch them. These learners need to see the teacher's body language and facial expression to interactive whiteboards, and handouts. During a lesson or classroom learners, they often prefer to take detailed notes to absorb the information. They learn through seeing and fully understand if they tend to prefer sitting at the front of the classroom. They may learn best from visual displays including: diagrams, illustrated textbook transparencies, videos, flipcharts, use of discussions, visual tent of a lesson. These learners think better in pictures or points in text. They tend to highlight important keypoints by using indexes, appendices, chapter summaries, etc.

Kinesthetic learners will likely learn at their best while touching and moving. It also has two sub-channels: kinesthetic (movement) and tactile (touch). They tend to lose concentration if there is little or no external stimulation or movement. When listening to lectures they may want to take notes for the sake of moving their hands. When reading, they like to scan the material first, and then focus in on the details (get the big picture first). They typically use color high lighters and take notes by drawing pictures, diagrams, or doodling. These learners learn through moving, doing, and touching. Kinesthetic learners learn best through a hands-on approach, actively exploring the physical world around them. They may find it hard to sit still for long periods and may become distracted by their need for activity and exploration. Some of the characteristics of kinesthetic learners are 1) take frequent study breaks, 2) work at a standing position, 3) listen to music while they study, 4) bring some type of "grip toy" to class to hold on to and, 5) skim through reading material to get a rough idea what it is about before sitting down to read it in detail.

According to the VAK theorists, there is no best learning style at the students' stages. No one person uses one style of learning exclusively, but they do have preferred learning styles. It is therefore important to attempt to cater for all learning styles during lessons to enable the most efficient learning to take place. They need to present information using all three styles, or a combination of two or three learning styles. This learning style is used to determine the students' dominant learning style. This allows all students the opportunity to become involved, no matter what their preferred style may be. Note taking is a complex activity that requires comprehension and selection of information and written production processes (Piolat, et al., 2005). It is a combination of those three learning styles. Kiewra in Dezure believed that students who take notes score higher on both immediate and delayed tests of recall and synthesis than students who do not take notes (Kiewra et al., 1991).

The use of media on note-taking will be different based on the availability and the students' 
characteristics to learn. Their media preferences indicates how well they enjoy learning or transform the lectures in written form; it can be through the traditional way using pen/pencil and paper (longhand), computer, or mobile-phone note. Through this study, it can be analyzed that numbers of words generated and the use of symbol or abbreviation will be fully determined by the use of various types of the media they students would love to prefer.

\section{SITUATIONS OF NOTE-TAKING}

Notes works as a memory aid. When people try to remember information they may use two types of memory aid, 1) internal memory aid relies on memory internal to one self and includes such strategies as mental rehearsing, mental retracing and mnemonic systems, and 2) external memory aid is a tangible physical external aid to the person such as writing on a calendar and making lists. Notes to aid recall were labeled under the term external memory aids by Intons-Peterson \& Fournier (1986) in Khan (1993) who suggested that these external memory aids were likely to be used in the following conditions.

a. Situations in which memory must override the potentially interfering events that often separate learning and recall such as having to go shopping after work. Here, a shopping list can be very important when there is intervening activity.

b. Situations where there is a longtime before learning and recall such as making an appointment for three months in the future.

c. Situations where there is a need for highly accurate or even verbatim recall of information as in the case of a journalist interviewing a person in order to write an article.

d. Situations when the to-beremembered intonation is difficult to understand and notes are needed to preserve important aspects such as in presentations or seminars.

e. Situations where there is limited time available for encoding, rehearsal \& using mnemonic techniques, such as writing a key point of information during a telephone conversation.

Intons-Peterson \& Fournier (1986) in Khan (1993) stated that external memory aids such as notes are likely to be used when a person knows that memory will be required and has the opportunity to prepare for recall.

\section{FORMAT OF NOTE-TAKING}

According to Parry, et.al, there are various formats of taking note used, namely; 1) outlining, 2) mindmapping, and 3) Cornell method. Different formats are used based on the way the lectures are presented.

\section{a. Outlining}

This involves a system of indenting information to show the relationship between main ideas, major supporting points and minor supporting details. This system is most useful when the lecture is presented in 
an organized fashion that moves from one point to the next. This kind of format is well-organized to see the main ideas and its sub-points.

\section{Outline Format}

I. First Main Idea
A. First Main Supporting Point
1. Supporting Detail
2. Supporting Detail
B. Second Main Supporting Point
1. Supporting Detail
2. Supporting Detail

II. Second Main Idea

Fig. 1: Outline Format (taken from

"Lecture Note-Taking" written by Parry, et al.)

b. Mind-Mapping

If the teacher moves from topic to topic and then back again, it may find helpful to take notes in a mind-map style. However, this may mean then the students need to rewrite them afterwards.

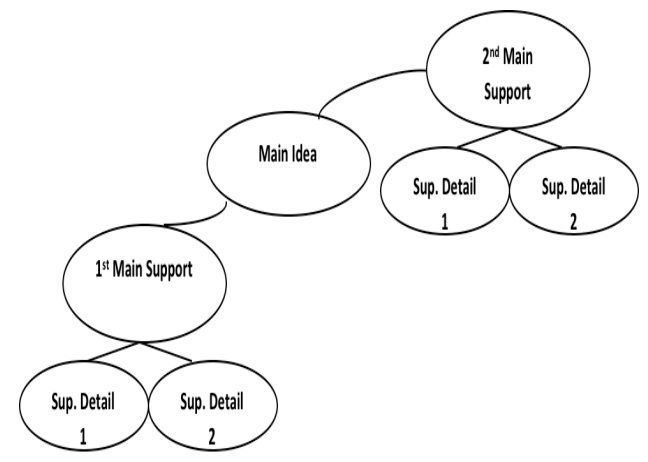

Fig. 2: Mind-Mapping Format

c. Cornell Method

Cornell note-taking method is proposed by Walter Pauk, an education professor at
Cornell University, New York. He introduced its effective use in his bestselling book "How to Study in College". The Cornell note-taking method uses a number of sections, listed as follows.

- Upper column

The students may fill this column with several options; 1) their names, 2) the heading (title of the topic at that day), or 3) date the notes taken. This column is not as essential as the next column to be explained but the content is sufficient to describe whose notes is, the big topic or materials the students learn at the specific day as well as the date.

- Right column (notes column)

As proposed by Pauk, the right column is used to capture the teacher's ideas and facts with students taking notes during the lecture in this column. It takes two thirds of the page. There are a number of advised points can be filled here; 1) testable materials, 2) important ideas, 3) definitions, and 4) supporting details. Further, to make it neat, support every point with bullet or symbols and skip the lines as well to 
understand and catch the point easily.

- Left column (cue column) It takes one third of the page. The left column (the cue column) is reserved for keywords and questions relevant to the notes on the right. After filling the right column, the students review their notes and write questions in the cue column to highlight main points, meanings, and relationships. The process of writing the questions in the cue column can help clarify meanings, reveal relationships, establish continuity, and strengthen memory. This column is also used in the review process when notes are studied after the class or before the test.

- Bottom column (summary)

The last column is left for summarizing the main points of the page, which again clarifies meanings and also makes review easier. This space needs only several sentences to make the concept simple.

When the note column, cue column and summary area are used for note-taking and for review, students have an organized system that can improve comprehension and achievement (Borr, et.al, 2012).
Cornell Notetaking Method

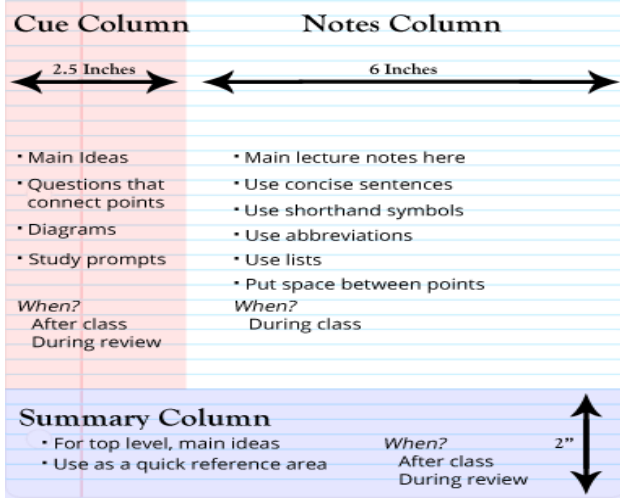

Fig. 3: Cornell Format

\section{OBJECTIVES OF NOTE-TAKING}

Notes can be defined as short condensations of a source material that are generated by writing them down while simultaneously listening, studying, or observing. Good notetaking practices can lead to efficient study practices, better course outcomes, and improved retention of content beyond a course's conclusion. Courses delivered by the teacher can be conveyed in various media such as lecturing, and visual aids. Though it is delivered in different ways, the act of writing notes creates a further learning opportunity. There are a number of benefits it could be withdrawn from note-taking, as outlined below.

a. Prevent the students from forgetting

Although all students attending a class listen to the same lecture, one student and another have different length of memory. Even not for an hour afterwards, the memory will stay only for minutes. Forgetting occurs very rapidly after listening to a lecture, or 
reading over informational material even if the material is engaging and interesting. So in other words, taking note might help to prevent the students from forgetting.

b. Exercise and encourage the students' concentration

Being active when attending class does not mean always be active in talking and proposing some ideas. Taking notes requires the students to be mentally active during a lecture or while reading. One student has to pay attention, interact with information, make decisions about what to record, and write. The students' minds are occupied with demanding tasks which results to less opportunity for the mind to wander. The students' actively focus on the lecturing and the materials given which later they need to make the information being conveyed become more simple and easy to understand.

c. Easily recall the information

Effective notes help students make connections to information that they already know. Note-taking supports information processing and serves as a means of external storage for later review (Piolat et al., in Hadwin, et al., 1999) Note-taking is useful because it provides a written record for review, which in turn promotes recall. Hartley in Hadwin (1999) stated that this benefit is not surprising because most students believe that writing the information will help them to remember and recall the information easily (Hadwin, et al., 1999).

d. Review the materials/concept during lecturing better When the students can recall the information easily, the will review the materials successfully. Notes can serve as a permanent record of the information from the lecture, and complete notes are best for students to use in review (Boyle in Borr, et al., 2012). The product of note-taking or the review is important for longterm use, and may participate well to the learning effect.

e. Help the students to do testable materials

After the afore-mentioned benefits go well, the test both in written or spoken will be better examined. One form of the evaluation is the test which is conducted at the end of the unit or semester (term). Effective notes will end up with a good memory when the students do the tests. Teachers generally expect students to remember and apply facts and ideas presented in lecture, in texts or oral test. Tests are based on key ideas teachers emphasize in their lectures and/or written material that supports key concepts or themes. In a nutshell, taking note might be 
one of the solutions to do the testable concept/material.

\section{LIMITATIONS OF NOTE-TAKING}

Taking note is not as simple as some people might think. It needs deep concentration and a good hearing. Once the students get intervenced or distracted by the environment (other students' voice, any sounds around), it will be hard to get back to the track again, unless they can catch up the rhyme or the key point again. According to Piolat et al. (2005), there are a number of limitations of doing the note-taking highlighted as follows.

a. Work extra to listen, understand, and jot the information down into written form. Piolat, et al. (2005) argued that note taking is often realized under severe time pressure. To take notes quickly, it is necessary to shorten and reduce information. It is impossible to jot all the information down conveyed during lecturing, so only those which become the key points and the elaborations need written.

b. Difficult to identify the key points.

Needs time to understand and get the key points or the main ideas of the lectures. Also, it requires focus to decide what is important to be written down in the notes, and coordinate the physical writing or typing of the notes as well. Further, Friedman pointed out that many mental processes occur simultaneously during the act of note-taking. What makes taking note complicated is the students should be able to remember the key points and elaborate into more details while they are listening to their teacher at once. Fact shows that people typically speak at a faster rate than which they are capable of writing or typing. As a result, it is extremely difficult to remember what the lecturing is about and write the associated information down before the teacher moves on to the next topic.

c. Difficult to identify good criteria of high-quality notes.

Since notes, commonly, are private and meaningful only for their note-taker. Moreover, Friedman argued that note quality cannot be assessed by anyone other than the notetaker itself, as a specific note format ideal for one person may not be the best quality or way to convey content to someone else. Different students will have different style of taking notes, in some situation there will be time where a student cannot understand and get the meaning of other student's notes, especially the connection between the key points and their elaboration. For example, single words in notes that appear to be nonsensical to others may cue the note-taker to think about a personal 
experience and how it relates to the topic of the notes. Also, there are some abbreviations or signs that only the note-taker understands. To support this point, Kiewra and colleagues found that reviewing selfproduced notes lead to better recall performance than reviewing another student's notes

\section{USE OF MEDIA ON NOTE- TAKING}

Doing the note-taking requires media as a place to pour the information down. It acts as a bowl to store all the information into written forms; the media used in this research are 1) paper and pen/pencil (longhand), 2) computer/laptop, and 3) mobile-phone note. Different students have their own preference to use media in note-taking. Each of them has its own benefits and drawbacks.

For paper and pen/pencil, the longhand note-takers have to prepare themselves first with those kinds of things before listening and jot the key points down. It is free and more convenient to draw or set the kinds of format of note-taking they want to use; whether it is outline, mid-mapping, or even using Cornell method. When they grasp the big ideas and start to write, they may write in any spaces in the paper. Also, it is easy and quick if they prefer and need to use abbreviations and symbols instead of writing the full sentences. The longhand note-takers may use any kinds of abbreviations or symbols as long as they understand the meaning.
If the note-takers find something to delete, they simply just need to scratch the words up, or in any case they need to add any abbreviations, symbols, or words, they just need to add them up. However, once mistakes found and needs deleting or scratching, the notes will be a bit dirty of the scratches and does not look neat anymore. Moreover, the note in paper is easily got lost unless it is well-organized. When the test comes and it needs note to review the materials, it would be time-waste to find the paper note if they are not wellfiled.

For computer/laptop-note, they also have spacious area to take note almost the same as the longhand notetakers. They may use the same format as well, but it takes time to draw the table and the balloons in mindmapping for example. The notes will never look untidy since the note-takers only simply need to press "Backspace or Delete" button on their computer/laptop. There will be no scratches like what have found in paper-note. However, there is limited action to take note on computer/laptop. The limitation can be because of the time needed to type or making symbols or tables. One thing to consider is the battery that must not be low; therefore, the note-takers need to ensure that the devise used is in hours conditions. Once, it is low-bat and off, the note-takers have to find any plug to charge it. Even, it is will be frustrating if it is in half-way of taking the note. Then, when the device is already in-use again, the note-takers will be somewhere of losing the concentration since they miss some of the 
information. One good thing is the file is easy to find and editable.

For the mobile-phone note, it has more limited action to type the information since the device used is not as wide as the laptop/computer or even paper. It is difficult to have all the same format as on paper and laptop since it has limited access. Basically, only simply outlining or numbering the note-takers can do. The size of the device also influences the speed of the note-taking. They take some more times to type on their mobile phone screen rather than get the main ideas of the information heard. Same case happens when the mobile is in low-bat condition. However, the file is easy to be accessed and portable since the device is easy to bring anywhere the note-takers go.

\section{METHODOLOGY}

This research was conducted in International Bali Tourism Institute (STPBI). As one of the well-known school for tourism, STPBI has its students to deal with tourism and hospitality as an industry that they will work in later. The students do not only learn about the subjects in specific industry, but also learn English as the language to facilitate their communication with the customers (guests). English is learnt every semester to keep and increase their ability in communicating both in spoken and written form and adjusted with the program they take in that semester. This research was done in Diploma III Hotel Management class when the students were learning about Business English for Hotel and
Tourism. There are seven units (chapters) they need to learn to obtain the objectives in one semester. This research was taken when they students were learning about Business Presentation (unit 3). The students were already accustomed by using the formats of note-taking since they were already familiar with them. Therefore, the teacher has ensured that the students were already familiar with three kinds of format explained previously; 1) outlining, 2) mindmapping, and 3) Cornell format. Procedures taken are explained as follows.

a. pre-test (nostudents' grouping) in multiple choice and TrueFalse type of questions. No discussion needed.

b. the next meeting, the students were grouped into three major categories depend on the media that they did the notetaking; 1) longhand, 2) computer/laptop-note, and 3) mobile-phone note. No matter any kinds of format the students chose, the major points was they did the notetaking though in different media. The class consisted of 27 students (10 female and 17 male), with the grouping: Group 1 (longhand; 4 females and 6 males)

Group 2 (computer/laptop note; 3 females and 6 males)

Group 3 (mobile-phone note; 3 females and 5 males) Each of the group covered high, average, and low achiever. 
c. the unit was explained in a series of meeting (1-3 meetings)

d. it was extra job for the teacher; not only explaining, but the teacher had to ensure that the students wrote or typed.

e. while explaining, the teacher also checked up the students' note by walking around.

f. post-test (the same test given as the pre-test)

g. distributed the questionnaire and did the interview with selected informants.

The data were collected through a series of method, namely:

a. Written test. The test was conducted in the forms of multiple choice and true false question. The test was done as individual pre- and post-test to assess individual's learning result before and after doing the note-taking.

b. Interview. Not all of the students were interviewed, just took 2 students from each group (there were 6 students in total). They were interviewed individually with the objective to identify how their learning process through this method, the excellence and the limitations as well.

c. Questionnaire. To accommodate the students' thought or point of views in written forms which were not revealed in interview session, questionnaire was distributed to all the students.

\section{FINDINGS AND DISCUSSION}

Based on the data, there were a number of findings found in this research, listed as follows.

\begin{tabular}{|l|l|l|l|}
\hline \multicolumn{1}{|c|}{ Findings } & \multicolumn{1}{|c|}{ Longhand } & \multicolumn{1}{c|}{ Computer/laptop } & Mobile-phone note \\
\hline gumber of words & $\begin{array}{l}\text { The students } \\
\text { generated fewer } \\
\text { words on paper. } \\
\text { Only key points } \\
\text { found with their } \\
\text { elaborations. }\end{array}$ & $\begin{array}{l}\text { More words } \\
\text { generated rather } \\
\text { than the longhand } \\
\text { on paper and pen } \\
\text { and mobile-phone } \\
\text { note as well. }\end{array}$ & $\begin{array}{l}\text { The least words were } \\
\text { taken by using } \\
\text { mobile-phone. It } \\
\text { might be because the } \\
\text { limited space the } \\
\text { students have to type } \\
\text { on their mobile- } \\
\text { phone note. }\end{array}$ \\
\hline $\begin{array}{l}\text { Abbreviations } \\
\text { and symbols }\end{array}$ & $\begin{array}{l}\text { Amongst these } \\
\text { three media, it was } \\
\text { found that there } \\
\text { were most } \\
\text { abbreviations and } \\
\text { symbols used in } \\
\text { longhand on } \\
\text { paper and pen. }\end{array}$ & $\begin{array}{l}\text { Only some } \\
\text { abbreviations and } \\
\text { symbols found but } \\
\text { at not many as in the } \\
\text { longhand, such as: } \\
\text { / meaning "or" } \\
\text { \& meaning "and" } \\
\text { \# meaning } \\
\text { "number" }\end{array}$ & $\begin{array}{l}\text { abbreviations or } \\
\text { symbols can be } \\
\text { counted. }\end{array}$ \\
\hline
\end{tabular}




\begin{tabular}{|c|c|c|c|}
\hline & $\begin{array}{l}\text { Some of } \\
\text { abbreviations } \\
\text { found were : } \\
\text { "w/" (meaning } \\
\text { with), "e.g" } \\
\text { (meaning } \\
\text { example) and } \\
\text { "w/o" (meaning } \\
\text { without) } \\
\text { Some of the } \\
\text { symbols used } \\
\text { were: } \\
\text { \# meaning } \\
\text { "number" } \\
\text { \& meaning "and" } \\
\pm \text { meaning } \\
\text { "approximately" } \\
\rightarrow \text { "next or leading } \\
\text { to" } \\
=\text { "equals to" }\end{array}$ & $\begin{array}{l}\text { The symbols were } \\
\text { those which easily to } \\
\text { find in the keyboard. } \\
\text { None of the } \\
\text { abbreviations found } \\
\text { since they preferred } \\
\text { to type the words } \\
\text { rather than shorten } \\
\text { them. }\end{array}$ & \\
\hline $\begin{array}{l}\text { Accurateness with } \\
\text { the lecturing }\end{array}$ & $\begin{array}{l}\text { More key points } \\
\text { and elaborations } \\
\text { (supporting } \\
\text { details) found }\end{array}$ & $\begin{array}{l}\text { Almost the same key } \\
\text { points as the } \\
\text { longhand but few } \\
\text { elaborations found }\end{array}$ & $\begin{array}{l}\text { No elaborations } \\
\text { found }\end{array}$ \\
\hline Looks & $\begin{array}{l}\text { Not really well- } \\
\text { organized since } \\
\text { some of the doodle } \\
\text { or scratches found } \\
\text { to delete the } \\
\text { previous wrong } \\
\text { words, unless the } \\
\text { notes would be } \\
\text { rewritten } \\
\text { afterwards. } \\
\end{array}$ & Well-organized & $\begin{array}{l}\text { Less well-organized } \\
\text { than } \\
\text { computer/laptop } \\
\text { note }\end{array}$ \\
\hline $\begin{array}{l}\text { Time to process } \\
\text { the note }\end{array}$ & $\begin{array}{l}\text { The students spent } \\
\text { longer time to } \\
\text { listen to the } \\
\text { lecture, in some } \\
\text { points they were } \\
\text { writing while } \\
\text { listening. It could } \\
\text { be done only by }\end{array}$ & $\begin{array}{l}\text { The students spent } \\
\text { longer time to type } \\
\text { and looked so busy } \\
\text { with their own } \\
\text { laptop. Both hands } \\
\text { were used to type. } \\
\text { They had to finish } \\
\text { their sentences and }\end{array}$ & $\begin{array}{l}\text { The students spent } \\
\text { longer time to their } \\
\text { mobile-phone screen. } \\
\text { Some of them hold } \\
\text { their mobile with } \\
\text { their left hand and } \\
\text { typed with their } \\
\text { right hand. The rest }\end{array}$ \\
\hline
\end{tabular}




\begin{tabular}{|l|l|l|l|}
\hline & $\begin{array}{l}\text { using one hand } \\
\text { either right- or left- } \\
\text { handed. For some } \\
\text { students, before } \\
\text { their sentences } \\
\text { were finished, } \\
\text { their eyes were } \\
\text { already back and } \\
\text { focus to the lecture } \\
\text { again. So, their } \\
\text { hands were active } \\
\text { while their ears } \\
\text { did as well. }\end{array}$ & $\begin{array}{l}\text { focus on the screen } \\
\text { and listened to the } \\
\text { lecture again. }\end{array}$ & $\begin{array}{l}\text { hold the device by } \\
\text { using their only right } \\
\text { palm while the right } \\
\text { thumb was typing. }\end{array}$ \\
\hline $\begin{array}{l}\text { Format of note- } \\
\text { taking }\end{array}$ & $\begin{array}{l}\text { Outlining } \\
\text { Mind-mapping } \\
\text { Cornell method }\end{array}$ & $\begin{array}{l}\text { Most of the students } \\
\text { did the note-taking } \\
\text { in outlining format }\end{array}$ & $\begin{array}{l}\text { Outlining but it did } \\
\text { not look so dear on } \\
\text { the supporting } \\
\text { details. It was more } \\
\text { into the points/bullet. }\end{array}$ \\
\hline Result of the test & \multicolumn{2}{|c|}{\begin{tabular}{l} 
No significant difference amongst these three different medias \\
\hline
\end{tabular}}
\end{tabular}

The following were the feedback given in each number of the questionnaire:

\begin{tabular}{|l|l|}
\hline \multicolumn{1}{|c|}{ QUESTION } & \multicolumn{1}{c|}{ RESPONSES } \\
\hline Question 1 & $\begin{array}{l}\text { Most of the students answered to recall the } \\
\text { information easily and prevent to forget. } \\
\text { Some of them answered to copy what their } \\
\text { friends did (copy the action of taking notes) } \\
\text { and it was the instruction from the teacher. } \\
\text { Few students answered to get their eyes on } \\
\text { during the class and to avoid the boredom. }\end{array}$ \\
\hline $\begin{array}{l}\text { Question } 2 \\
\text { When would you not to take a note? }\end{array}$ & $\begin{array}{l}\text { Some of them responded when they already } \\
\text { knew the information so nothing was useful } \\
\text { to be written down since it was a very } \\
\text { common thing to remember. } \\
\text { The rest answered when the information } \\
\text { was repeated many times, and when they } \\
\text { missed the information from the teacher } \\
\text { since they were busy to write on the } \\
\text { previous information and did not really get } \\
\text { focus on the latest information. }\end{array}$ \\
\hline Question 3 & $\begin{array}{l}\text { This question seemed misleading. There } \\
\text { were various kinds of answer. Some of their }\end{array}$ \\
\hline
\end{tabular}




\begin{tabular}{|c|c|}
\hline & $\begin{array}{l}\text { responses were like 1) the format, 2) by } \\
\text { listening to the key points, 3) in the silent } \\
\text { situation, 4) by using different media. }\end{array}$ \\
\hline $\begin{array}{l}\text { Question } 4 \\
\text { Do you date your note? }\end{array}$ & $\begin{array}{l}\text { Only few students dated their notes; most of } \\
\text { them did not consider it was important. } \\
\text { Basically, the heading would be the tittle of } \\
\text { the concept, the subject or even their name }\end{array}$ \\
\hline $\begin{array}{l}\text { Question } 5 \\
\text { Do you mark or highlight any of your } \\
\text { notes? }\end{array}$ & $\begin{array}{l}\text { Only the computer/laptop note-takers } \\
\text { usually highlighted their notes. They } \\
\text { believed that by highlighting or giving mark } \\
\text { would be the critical point. }\end{array}$ \\
\hline $\begin{array}{l}\text { Question } 6 \\
\text { Do you use diagram in your note? }\end{array}$ & $\begin{array}{l}\text { Paper eased the longhand note-taker to use } \\
\text { diagram or table or any kinds of chart. Some } \\
\text { of them used diagram when it is needed. } \\
\text { However, only few of the laptop note-takers } \\
\text { used diagram and none of the mobile-phone } \\
\text { used it since it has limited action and space. }\end{array}$ \\
\hline $\begin{array}{l}\text { Question } 7 \\
\text { How do you file your note? }\end{array}$ & $\begin{array}{l}\text { Some of them saved the notes in spiral } \\
\text { binding file (the longhand on paper and } \\
\text { pen), inserted the paper in the guidebook, or } \\
\text { simply folded the paper. Another, the notes } \\
\text { were saved in the laptop document and } \\
\text { once they would like to find it, then just } \\
\text { searched and type the file, in seconds the file } \\
\text { would be easily appeared. }\end{array}$ \\
\hline $\begin{array}{l}\text { Question } 8 \\
\text { How often do you refer back to your } \\
\text { note? }\end{array}$ & $\begin{array}{l}\text { Half of them referred back their note } \\
\text { especially when the test would be coming } \\
\text { over, some of them preferred to see the } \\
\text { guide book or the handout given; the rest } \\
\text { did not take it seriously. }\end{array}$ \\
\hline $\begin{array}{l}\text { Question } 9 \\
\text { Do you always understand your note? }\end{array}$ & $\begin{array}{l}\text { Only the note-takers understood their notes, } \\
\text { even when it was not so well-organized. All } \\
\text { of the students understood their notes since } \\
\text { they were the one who made it. }\end{array}$ \\
\hline $\begin{array}{l}\text { Question } 10 \\
\text { Do you ever re-write/re-organized your } \\
\text { notes? }\end{array}$ & $\begin{array}{l}\text { None of them re-wrote their note } \\
\text { afterwards, as long as their notes were } \\
\text { understandable, they preferred not to re- } \\
\text { organize them. }\end{array}$ \\
\hline $\begin{array}{l}\text { Question } 11 \\
\text { Do you use any abbreviations and } \\
\text { symbols in your note? }\end{array}$ & $\begin{array}{l}\text { Most of the abbreviations and symbols } \\
\text { would be likely on the longhand one and the } \\
\text { least would be on the mobile-phone note. }\end{array}$ \\
\hline
\end{tabular}




\begin{tabular}{|l|l|}
\hline $\begin{array}{l}\text { Question } 12 \\
\text { Do you copy some notes from the } \\
\text { board? }\end{array}$ & $\begin{array}{l}\text { All of them copied some notes from the } \\
\text { board since all the board notes were } \\
\text { significantly meaningful. }\end{array}$ \\
\hline $\begin{array}{l}\text { Question } 13 \\
\text { Do you ever doodle while taking a note? }\end{array}$ & $\begin{array}{l}\text { Most of the longhand note-takers always } \\
\text { doodle while listening to the lecture; they } \\
\text { might draw miscellaneous things around } \\
\text { the paper. For the laptop note-takers, they } \\
\text { rarely doodled but open another file or any } \\
\text { website if there were pause in the lecture or } \\
\text { nothing was important to be jotted down. } \\
\text { For the mobile-phone note-takers, they } \\
\text { preferred to googling or opened the social } \\
\text { media or replied the chat. }\end{array}$ \\
\hline $\begin{array}{l}\text { Question 14 } \\
\text { Do you prefer lined or plain paper? }\end{array}$ & $\begin{array}{l}\text { This question was actually to the longhand } \\
\text { note-takers, but as a matter of fact all of the } \\
\text { students answered it. Most of them } \\
\text { preferred to have the lined one since they } \\
\text { did not need to make the lines again. Lines } \\
\text { were used to make the notes more } \\
\text { organized and looked neat. While the rest } \\
\text { preferred to plain one so they could make } \\
\text { the notes as imaginative and in free design. } \\
\text { They thought thatlined paper would border } \\
\text { their creative thinking. }\end{array}$ \\
\hline $\begin{array}{l}\text { Only laptop note-takers used different } \\
\text { colours: which was only red to highlight the } \\
\text { heading. }\end{array}$ \\
\hline Do you use different colours in writing \\
the note?
\end{tabular} \mid \begin{tabular}{l}
\hline \\
\hline
\end{tabular}

\section{CONCLUSION}

There were three different medias being analyzed in this study; 1) longhand on paper and pen, 2) computer/laptop, and 3) mobile-phone note. In terms of their cognitive as a learning result, there was no significant difference on their score between longhand, laptop, and mobile-phone note-takers. Their preference on the media use on note-taking indicates numbers of word generated, abbreviations and symbols, looks, accurateness with the lecture time to process the note, and format of notetaking.

\section{REFERENCES}

Borr, Mari. et al. (2012). The Impact of the Cornell Note-Taking Method on Students' Performance in a High School Family and Consumer Sciences Class. Journal of Family \& Consumer Sciences Education, 30(1)

Dezure, D., Matthew Kaplan, \& Martha A. Deerman. (2001). Research on Student Notetaking: 
Implications for Faculty and Graduate Student Instructors. CRLT Occasional Paper No. 16 Friedman, Michael. (2014). Notes on Note-Taking: Review of Research and Insights for Students and Instructors. Harvard Initiative for Learning and Teaching. Harvard University

Hadwin, A., John Kirby, \& Rosamund Woodkouse, (1999). Individual Differences in Notetaking, Summari zation, and Learning from Lectures. The Alberta Journal of Educational Research Vol. XLV, No. 1, Spring 1999,1-17

Khan, Fawzia. (1993). A Survey of NoteTaking Practices. HewlettPackard Company.
Parry. A, Cameron. J, \& Klassen, C. Lecture Note-Taking. Douglas College Learning Centre.

Piolat, A., Thierry Olive, \& Ronald Kellogg. (2005). Cognitive Effort during Note Taking. Wiley Inter Science

Venkatraman, Belaji. (2007). Visual, Auditory, and Kinesthetic Learning Styles (VAK). Retrieved on 25 June 2018 from https://www. linkedin.com/pulse/visualauditory-kinesthetic-learningstyles-vak-balaji-venkatraman 